\title{
Phenotypic variation of yielding of medium-early cultivars of table potato
}

\author{
Fenotypowa zmienność plonowania średnio wczesnych odmian ziemniaka \\ jadalnego
}

Marek Kołodziejczyk

\author{
Department of Agroecology and Crop Production, University of Agriculture in Krakow, Al. Mickiewicza 21, 31-120 \\ Krakow, \\ $\bowtie$ e-mail: m.kolodziejczyk@ur.krakow.pl
}

\begin{abstract}
The aim of the study was to analyse the genotypic and environmental variation in yield, as well as the structure of the yield of tubers of medium-early cultivars of table potato. The field study was carried out in the years 2015-2019 at the experimental station in Prusy near Krakow $\left(50^{\circ} 07^{\prime} \mathrm{N}, 20^{\circ} 05^{\prime} \mathrm{E}\right)$ on chernozem soil. The following five potato cultivars were evaluated: Finezja, Oberon, Laskara, Satina and Tajfun. The total and commercial yield of tubers, the average tuber mass, the quantity of tubers from a plant, as well as the share of the fraction of large, commercial and small tubers were determined in the study. Of the potato features that were evaluated, the share of the commercial tuber fraction was the most stable. A low diversity was also found in the case of total and commercial yield of tubers, whereas the share of the fraction of small tubers was the least stable feature. The size of yields and their structure were determined mostly by environmental factors. Only in the case of the share of fractions of large and small tubers were the varietal properties more decisive than the genotypic-environmental interaction.
\end{abstract}

\begin{abstract}
Key words: potato cultivars, tuber yield, variability of characteristics, yield structure
Celem badań była analiza zmienności genotypowej i środowiskowej plonu oraz struktury plonu bulw średnio wczesnych odmian ziemniaka jadalnego. Badania polowe realizowano w latach 2015-2019 w Stacji Doświadczalnej w Prusach k. Krakowa ( $50^{\circ} 07^{\prime} \mathrm{N}$ i $\left.20^{\circ} 05^{\prime} \mathrm{E}\right)$ na czarnoziemie typowym. Ocenie poddano 5 odmian ziemniaka: Finezja, Oberon, Laskara, Satina i Tajfun. W badaniach określono plon ogólny i handlowy bulw, średnią masę bulwy, ilość bulw z rośliny oraz udział frakcji bulw dużych, handlowych i małych. Spośród ocenianych cech ziemniaka najbardziej stabilny okazał się udział frakcji bulw handlowych. Małe zróżnicowanie stwierdzono także w przypadku plonu ogólnego i handlowego bulw, natomiast najmniej stabilną cechą był udział frakcji bulw małych. Wielkości plonów oraz ich struktura najsilniej determinowane były czynnikami środowiska. Właściwości odmianowe w większym stopniu niż interakcja genotypowo-środowiskowa decydowały tylko o udziale frakcji bulw dużych oraz małych.
\end{abstract}

Słowa kluczowe: odmiany ziemniaka, plon bulw, struktura plonu, zmienność cech

\section{Introduction}

Poland's climatic-soil conditions are favorable for potato cultivation. However, the high amplitude of yields obtained in individual years is indicative of a significant effect of the weather course on the utilization of the yielding potential of this crop. In the study conducted by Wierzbicka and Trawczyński (2016), cultivars of table potato made use of the yielding potential, on average, at a level of $76 \%$. The size of actual tuber yields is determined both by genetic properties, habitat and agrotechnical conditions, as well as by the interaction of these factors. Rijk et al. (2013) believe that the yielding potential of late cultivars of potato stems from the better use of habitat conditions, mainly the amount of photosynthetically active solar energy that reaches the plant, whereas early cultivars use genetic sources more effectively. Habitat factors that determine the environmental variability include soil and weather conditions, which, according to Drzazga and Krajewski (2001), have a stronger effect on the character of the genotype-environmental interaction. According to Węgrzyn (2001), low, and ideally zero interaction between the genotype and weather conditions, and any interaction between the genotype and localities facilitate recommendation of the applicability of cultivars for cultivation in a given region. This is because changes in weather conditions are more and more frequent and intense, both over a short and long period of time, as opposed to edaphic factors (physicochemical properties of soil), whose character is rather stable.

Owing to its capacity to produce substantial plant biomass as well as its poorly developed root system, the potato is characterized by considerable water requirements. The potato 
water requirement is highest during tuberization and in the period from flowering to maturation (Chmura et al., 2013). Both deficiency and excess of precipitation in these periods has a negative effect on potato yielding (Radzka et al., 2015). Temperature also plays a significant role in shaping the size of the potato tuber yield. This is because temperature, in conjunction with moisture conditions, by extending or shortening the duration of individual developmental stages, diversifies the magnitude of yield components such as the number of set tubers and their average mass (Rykaczewska, 2015). Learning about the relationships between yield components and the impact of weather conditions on the shaping of these features is an important issue both in the context of tuber production and cultivation of new cultivars.

The aim of the study was to analyze the share of genotypic and environmental variability in the total variability of yield and the shaping of the tuber yield components of medium-early table potato cultivars. The research hypothesis assumes that the varietal properties are the main factor determining the size and structure of the potato tuber yield.

\section{Material and Methods}

The study was conducted in the years 2015-2019 at the Experimental Station in Prusy $\left(50^{\circ} 07^{\prime} \mathrm{N}\right.$ and $20^{\circ} 05^{\prime} \mathrm{E}$ ), which belongs to the University of Agriculture in Krakow. The single-factor field experiment was set up on Haplic Chernozem soil $(C W t)$, classified in the very good wheat complex and soil quality class I, in a randomized block design with 3 replications. The arable soil layer $(0-30 \mathrm{~cm})$ revealed: medium abundance in phosphorus (124-147 mg kg-1); medium to high potassium content (183-252 $\left.\mathrm{mg} \mathrm{kg}^{-1}\right)$; medium magnesium abundance (86-98 $\left.\mathrm{mg} \mathrm{kg}^{-1}\right)$ and slightly acid $\mathrm{pH}(\mathrm{pH}$ 5.8-6.1). The study determined the total and commercial yield of tubers, the number of tubers from a plant, the average tuber mass, as well as the share of large, commercial and fine medium-early cultivars of table potato: Finezja, Oberon, Laskara, Satina and Tajfun.

The potatoes were planted in the second ten days of April at $75 \times 35 \mathrm{~cm}$ spacing, and the harvest was carried out in the latter part of September. The size of an experimental plot for harvest was $15.75 \mathrm{~m}^{2}$. Winter wheat was the forecrop. Mineral fertilization (150 kg N, $39.2 \mathrm{~kg} \mathrm{P}$ and $199.2 \mathrm{~kg} \mathrm{~K}_{2} \mathrm{O}$ per $1 \mathrm{ha}$ ) was used in potato cultivation. The weed infestation was reduced by a mechanical-chemical method, using double ridging and herbicides: a soil-applied one, against dicotyledonous weeds (Command 480 EC $0.21 \mathrm{ha}^{-1}$ ), and a foliar one against monocotyledonous weeds (Targa Super 05 EC $1.51 \mathrm{ha}^{-1}$ ). In the potato growing season, $2-3$ fungicidal measures (Ridomil Gold MZ 67.8 WG $2 \mathrm{~kg} \mathrm{ha}^{-1}$, Infinito 687.5 SC $\left.1.51 \mathrm{ha}^{-1}\right)$ and 1-2 insecticide measures were applied (Actara 25 WG $0.08 \mathrm{~kg} \mathrm{ha}^{-1}$, Karate Zeon 050 CS 0.151 ha-1 $^{-1}$. Tubers were harvested at their full physiological maturity. During the harvest, the total tuber yield was determined, and samples were taken to determine its structure. The size of the commercial yield of tubers was estimated based on the share of the commercial tuber fraction with transverse diameter more than $3.5 \mathrm{~cm}$, separating tubers which were heavily deformed, greenish (over $20 \%$ surface area), and with symptoms of fungal and bacterial diseases. Small tubers consisted of the fraction with diameter below $3.5 \mathrm{~cm}$, and large tubers with the fraction with diameter above $5 \mathrm{~cm}$. The research was carried out according to the methodology of post-registration trials.

The obtained study results were subjected to statistical assessment by carrying out analysis of variance. The significance of differences between the plots was verified using Tukey's test at a significance level of $\alpha=0.05$. The variability of features of individual potato cultivars was assessed using the variation coefficient. To determine the share of individual sources of variation (genetic and environmental) and their cooperation in the total variation (phenotypic) of the studied features, an assessment of variation components was conducted, according to a random model using Statistica 13.1 software. The empirical values of the mean squares obtained from the analysis of variance were compared with their expected values. By solving the system of equations in this way, an estimate of the variance components corresponding to individual sources of variability was obtained. The mutual relations of the estimated variance components and their percentage structure were the basis for the assessment of the influence of the varietal factor (genotypic variability) and the years of study (environmental variability) on the total (phenotypic) variability of the tuber yield and the features of the yield structure.

The years of the study differed significantly in term of thermal conditions, as well as in the quantity and distribution of precipitation, which finds reflection in Sielianinov's coefficient values, which are a measure of the efficiency of precipitation in a given period (Table 1). In the five-year study 
cycle, three growing periods of potato were classified as dry, and two as humid. The distribution of precipitation was erratic, and its sum from April to August in individual years of the study varied from 292 to $444 \mathrm{~mm}$. The best humidity conditions were in 2017 , when the sum of precipitation was close to precipitation requirements for medium-early potato cultivars, and air temperature was the lowest in the study cycle. Particularly unfavorable weather conditions were recorded in 2018, where air temperature and precipitation deficiency were significantly higher than in other growing periods.

Table 1

Weather conditions during potato vegetation in years 2015-2019

Tabela 1

Warunki pogodowe w okresie wegetacji ziemniaka w latach 2015-2019

\begin{tabular}{|c|c|c|c|c|c|c|}
\hline \multirow{2}{*}{ Month/Year } & \multirow{2}{*}{$\begin{array}{l}\text { Mean of tem- } \\
\text { perature } \\
\left({ }^{\circ} \mathrm{C}\right)\end{array}$} & \multirow{2}{*}{$\begin{array}{c}\text { Sum of ra- } \\
\text { inffals } \\
(\mathrm{mm})\end{array}$} & \multicolumn{2}{|c|}{$\begin{array}{l}\text { Differences between the rainffal } \\
\text { and: }\end{array}$} & \multirow{2}{*}{$\begin{array}{l}\text { Sielianinow coef- } \\
\text { ficient }\end{array}$} & \multirow{2}{*}{$\begin{array}{l}\text { The month's classifica- } \\
\text { tion** }\end{array}$} \\
\hline & & & $\begin{array}{c}\text { neets* } \\
(\mathrm{mm})\end{array}$ & $\begin{array}{l}\text { long-term } \\
(\mathrm{mm})\end{array}$ & & \\
\hline \multicolumn{7}{|c|}{2015} \\
\hline IV & 9,1 & 24 & -39 & -24 & 0,9 & dry \\
\hline $\mathrm{V}$ & 13,3 & 101 & 42 & 22 & 2,5 & very wet \\
\hline VI & 17,5 & 53 & -24 & -36 & 1,0 & fairly dry \\
\hline VII & 20,6 & 72 & -33 & -13 & 1,1 & fairly dry \\
\hline VIII & 22,0 & 42 & -64 & -35 & 0,6 & very dry \\
\hline mean & 16,5 & 292 & -40 & -86 & 1,2 & fairly dry \\
\hline \multicolumn{7}{|c|}{2016} \\
\hline IV & 9,5 & 59 & -6 & 11 & 2,1 & wet \\
\hline $\mathrm{V}$ & 14,5 & 41 & -25 & -38 & 0,9 & dry \\
\hline VI & 18,8 & 60 & -23 & -29 & 1,1 & fairly dry \\
\hline VII & 19,6 & 93 & -7 & 8 & 1,5 & optimal \\
\hline VIII & 18,5 & 62 & -16 & -15 & 1,1 & fairly dry \\
\hline mean & 16,5 & 315 & -77 & -63 & 1,3 & fairly dry \\
\hline \multicolumn{7}{|c|}{2017} \\
\hline IV & 7,6 & 111 & 55 & 63 & 4,9 & extremely wet \\
\hline $\mathrm{V}$ & 14 & 84 & 12 & 5 & 1,9 & fairly wet \\
\hline VI & 18,8 & 45 & -38 & -44 & 0,8 & dry \\
\hline VII & 19,2 & 84 & -14 & -1 & 1,4 & optimal \\
\hline VIII & 20,3 & 84 & -13 & 7 & 1,3 & optimal \\
\hline mean & 16,0 & 408 & 2 & 30 & 2,1 & wet \\
\hline \multicolumn{7}{|c|}{2018} \\
\hline IV & 14,7 & 7 & -84 & -41 & 0,2 & extremely dry \\
\hline $\mathrm{V}$ & 17,5 & 62 & -18 & -17 & 1,2 & fairly dry \\
\hline VI & 18,5 & 86 & 5 & -3 & 1,5 & optimal \\
\hline VII & 19,9 & 120 & 19 & 35 & 1,9 & fairly wet \\
\hline VIII & 20,8 & 56 & -44 & -21 & 0,9 & dry \\
\hline mean & 18,3 & 331 & -122 & -47 & 1,1 & fairly dry \\
\hline \multicolumn{7}{|c|}{2019} \\
\hline IV & 10,3 & 76 & 7 & 28 & 2,5 & very wet \\
\hline $\mathrm{V}$ & 12,4 & 205 & 151 & 126 & 5,4 & extremely wet \\
\hline VI & 22,2 & 22 & -78 & -67 & 0,3 & extremely dry \\
\hline VII & 19,2 & 53 & -45 & -32 & 0,9 & dry \\
\hline VIII & 20,5 & 88 & -10 & 11 & 1,4 & optimal \\
\hline mean & 16,9 & 444 & 25 & 66 & 2,1 & wet \\
\hline
\end{tabular}

* rainffal needs according to Klatt, citation for Nyc (2006); ** classification according to Skowera and Puła (2004) 


\section{Results and Discussion}

Mean values of total yield of tubers of the studied table potato cultivars' shape were in a narrow range from 60.0 to $63.8 \mathrm{t} \mathrm{ha}^{-1}$ (Table 2). Commercial yields of tubers were more varied, ranging from 50.8 to $58.8 \mathrm{t} \mathrm{ha}^{-1}$. In the five-year study cycle, the 'Tajfun' cultivar was characterized by the highest variation in total yield (11.8\%), and 'Oberon'the highest variation in commercial yield (14.2\%). 'Laskara' and 'Satina' cultivars had the most stable tuber yields. In the study by Radzka (2015), variation in yielding of 9 medium-early potato cultivars, assessed at six locations, ranged between 14.1 and 19.4\%. Sawicka and Pszczółkowski (2017) showed a greater variation in yielding of early potato cultivars $(15.0-42.8 \%)$. The sizes of the total and commercial yield of tubers were determined mostly by weather conditions- 59.9 and $46.7 \%$ of total variation, respectively (Table 3). The interaction between the cultivars and years was $29.5 \%$ responsible for the variation in the total yield and $38.0 \%$ for the variation in the commercial yield of tubers. Varietal properties explained $0.6 \%$ of the variability in the total yield, and $5.5 \%$ in the commercial yield. A study by Sawicka et al. (2011) also confirms the decisive impact of weather conditions (with a small role of the genetic factor in shaping the total yield of tubers of medium-late and late cultivars of potato). On the other hand, according to Sawicka and Pszczółkowski (2017), the interaction between cultivars and years is the primary source of variation in tuber yield in the group of very early and early potato cultivars.

Table 2

Tabela 2

Charactertistics of varialibity of tuber yield and its structure

Charakterystyka zmienności plonu bulw oraz jego struktury

\begin{tabular}{|c|c|c|c|c|c|c|}
\hline \multirow{2}{*}{ Feature } & \multirow{2}{*}{ Statistical measure } & \multicolumn{5}{|c|}{ Cultivar } \\
\hline & & Finezja & Oberon & Laskara & Satina & Tajfun \\
\hline total yield of tubers $\left(\mathrm{t} \mathrm{ha}^{-1}\right)$ & $\begin{array}{c}\text { arithmetic mean } \\
\text { variability range } \\
\qquad V^{*}\end{array}$ & $\begin{array}{c}60.0 \\
52.0-69.1 \\
9.7\end{array}$ & $\begin{array}{c}61.7 \\
54.3-70.8 \\
9, .0\end{array}$ & $\begin{array}{c}61.9 \\
57.1-69.2 \\
6.0\end{array}$ & $\begin{array}{c}63.8 \\
55.1-72.0 \\
8.9\end{array}$ & $\begin{array}{c}62,1 \\
46.8-70.2 \\
11.8\end{array}$ \\
\hline commercial yield of tubers $\left(\mathrm{t} \mathrm{ha}^{-1}\right)$ & $\begin{array}{c}\text { arithmetic mean } \\
\text { variability range } \\
\qquad V^{*}\end{array}$ & $\begin{array}{c}53.9 \\
46.0-67.1 \\
11.2\end{array}$ & $\begin{array}{c}52.1 \\
38.8-65.1 \\
14.2\end{array}$ & $\begin{array}{c}55.7 \\
50.8-66.9 \\
8.5\end{array}$ & $\begin{array}{c}58.8 \\
52.0-65.2 \\
7.6\end{array}$ & $\begin{array}{c}50.8 \\
46.2-66.0 \\
12.2\end{array}$ \\
\hline average weight of tubers $(\mathrm{g})$ & $\begin{array}{c}\text { arithmetic mean } \\
\text { variability range } \\
\qquad V^{*}\end{array}$ & $\begin{array}{c}141 \\
88-207 \\
33.9\end{array}$ & $\begin{array}{c}124 \\
87-197 \\
31.1\end{array}$ & $\begin{array}{c}146 \\
110-185 \\
16.7\end{array}$ & $\begin{array}{c}142 \\
104-212 \\
27.8\end{array}$ & $\begin{array}{c}136 \\
99-222 \\
30.6\end{array}$ \\
\hline number of tubers per plant & $\begin{array}{c}\text { arithmetic mean } \\
\text { variability range } \\
\qquad V^{*}\end{array}$ & $\begin{array}{c}12.2 \\
7.0-17.2 \\
29.0\end{array}$ & $\begin{array}{c}13.8 \\
7.4-18.6 \\
29.4\end{array}$ & $\begin{array}{c}11.8 \\
7.8-16.0 \\
23.3\end{array}$ & $\begin{array}{c}12.2 \\
7.0-17.4 \\
30.0\end{array}$ & $\begin{array}{c}12.5 \\
5.8-18.6 \\
32.9\end{array}$ \\
\hline share of commercial tubers $(\%)$ & $\begin{array}{c}\text { arithmetic mean } \\
\text { variability range } \\
\qquad V^{*}\end{array}$ & $\begin{array}{c}97.1 \\
91.3-99.8 \\
2.5\end{array}$ & $\begin{array}{c}91.4 \\
74.4-98.9 \\
9.0\end{array}$ & $\begin{array}{c}96.6 \\
91.8-99.6 \\
2.4\end{array}$ & $\begin{array}{c}95.7 \\
87.9-99.8 \\
3.7\end{array}$ & $\begin{array}{c}95.0 \\
83.3-98.9 \\
5.5\end{array}$ \\
\hline share of large tubers (\%) & $\begin{array}{l}\text { arithmetic mean } \\
\text { variability range } \\
\qquad V^{*}\end{array}$ & $\begin{array}{c}61.1 \\
44.0-99.0 \\
32.9\end{array}$ & $\begin{array}{c}48.0 \\
32.7-82.1 \\
35.8\end{array}$ & $\begin{array}{c}73.0 \\
61.0-67.4 \\
13.4\end{array}$ & $\begin{array}{c}75.8 \\
60.0-88.8 \\
13.3\end{array}$ & $\begin{array}{c}70.5 \\
52.7-89.0 \\
15.2\end{array}$ \\
\hline share of small tubers $(\%)$ & $\begin{array}{c}\text { arithmetic mean } \\
\text { variability range } \\
V^{*}\end{array}$ & $\begin{array}{c}2.9 \\
0.2-8.7 \\
84.1\end{array}$ & $\begin{array}{c}8.6 \\
1.1-25.6 \\
96.0\end{array}$ & $\begin{array}{c}3.4 \\
0.4-8.2 \\
67.4\end{array}$ & $\begin{array}{c}4.3 \\
0.2-12.1 \\
82.0\end{array}$ & $\begin{array}{c}5.0 \\
1.1-16.7 \\
105.0\end{array}$ \\
\hline
\end{tabular}

* coefficient of variation (\%) 
Variance components of examined characteristics of potato

Komponenty wariancyjne badanych cech ziemniaka

\begin{tabular}{|c|c|c|c|c|c|c|c|c|}
\hline \multirow[b]{2}{*}{ Feature } & \multicolumn{4}{|c|}{ Variance components } & \multicolumn{4}{|c|}{ Proportion of total variation $(\%)$} \\
\hline & cultivars & years & $\begin{array}{c}\text { cultivars } \\
\text { x years }\end{array}$ & error & cultivars & years & $\begin{array}{c}\text { cultivars } \\
\text { x years }\end{array}$ & error \\
\hline total yield of tubers & 0.2 & $22.6^{* * *}$ & $11.1^{* *}$ & 3.8 & 0.6 & 59.9 & 29.5 & 10.0 \\
\hline commercial yield of tubers & 2.3 & $19.7^{* *}$ & $15.7^{* *}$ & 3.7 & 5.5 & 46.7 & 38.0 & 8.8 \\
\hline average weight of tuber & 87.9 & $1237.8^{* *}$ & $507.7^{* *}$ & 78.6 & 4.6 & 64.7 & 26.6 & 4.1 \\
\hline numer of tubers per plant & 0.6 & $11.0^{* *}$ & $3.6^{* *}$ & 1.2 & 3.6 & 67.2 & 22.1 & 7.1 \\
\hline share of commercial tubers & 2.5 & $14.0^{* *}$ & $10.9^{* *}$ & 2.7 & 8.2 & 46.5 & 36.3 & 8.9 \\
\hline share of large tubers & $112.5^{* *}$ & $154.5^{* *}$ & $71.3^{* *}$ & 6.3 & 32.7 & 44.8 & 20.7 & 1.8 \\
\hline share of small tubers & $84.8^{*}$ & $151.1^{* *}$ & $99.9^{* *}$ & 6.2 & 24.8 & 44.2 & 29.2 & 1.8 \\
\hline
\end{tabular}

The years of the study played the dominant role in phenotypic variation in tuber yield components. The share of this source of variation in the shaping of the average tuber mass and the number of tubers per plant were 64.7 and $67.2 \%$, respectively. Genotypic variation in these features constituted 4.6 and $3.6 \%$ of total variation, respectively. A higher share of environmental variation than genotypic variation in the shaping of yield components results in a considerable diversification in yields in individual years. As studies by Zabihi-e-Mahmoodabad (2011) and by Kołodziejczyk (2014) indicate, the average tuber mass determines the size of yield more strongly than the number of tubers per plant. In the conducted study, the coefficient of variation for the average tuber mass was within the range from 16.7 to $33.9 \%$, whereas for the number of tubers per plant-from 23.3 to $32.9 \%$. The 'Laskara' cultivar was characterized by the greatest stability of these features, whereas the 'Tajfun' cultivar was the least stable in terms of the number of set tubers, and 'Finezja' in the case of the average tuber mass. The share of the commercial tuber fraction (with diameter $>3.5 \mathrm{~cm}$ ) in the total yield of the studied medium-early cultivars of table potato was within a wide range from 91.4 to $97.1 \%$, and the coefficient of variation-from 2.4 to $9.0 \%$. A less stable feature was the share of the large tuber fraction (with diameter $>5 \mathrm{~cm}$ ), ranging from 48.0 to $75.8 \%$, and the coefficient of variation, ranging from 13.3 to $35.8 \%$. The share of the small tuber fraction in the total yield ranged from 2.0 to $8.6 \%$, and the coefficient of variation-from 67.4 to $105.0 \%$. The years of the study played a dominant role in phenotypic variation in the share of the fraction of commercial, large and small tubers in the total yield: $46.5,44.8$ and $44.2 \%$ of total variation, respectively. Genotypic variation constituted $8.2 \%$ of the total variation in the share of commercial tuber mass, as well as $32.7 \%$ of the share of large tuber mass in yield. The most important factors that decide on environmental variation may include: quality of seed-potatoes (size, health), diversity of the soil environment (abundance in nutrients, $\mathrm{pH}$ ), as well as the impact of weather conditions (precipitation, temperature, light conditions). The last group of environmental factors, according to Stefańczyk and Śliwka (2013), has a significant effect on potato tuberization. Studies conducted by many authors also point to a considerable environmental variation in the features of the tuber yield structure (Bussan et al., 2007; Gauch et al., 2008; Pytlarz-Kozicka 2004]. In a study by Sawicka and Pszczółkowski (2017), environmental factors exerted a decisive impact on the number of shoots and the share of the mass of tubers with diameter of 4-5 cm. The share of small tubers (diameter below $4 \mathrm{~cm})$ and large ones $(5-6$ and $>6 \mathrm{~cm})$ depended mainly on the genotype-environmental interaction. The source literature indicates that the main cause of inter-cultivar differences in stability of features is the genotype-environmental interaction, described as a changeable expression of a given feature in response to specific environmental conditions (Gauch et al., 2008; Jankowska et al., 2015; Mądry and Iwańska, 2011).

The study showed that the average tuber mass correlated positively with the share of the fraction 
of commercial and large tubers, and negatively with the total yield, number of tubers per plant, and with the share of small tubers (Table 4). On the other hand, the number of tubers per plant was positively correlated with the total yield and the share of small tubers, and negatively correlated with the share of the fraction of commercial and large tubers. The observed relationships find confirmation in the study by Sawicka and Pszczółkowski (2017). On the other hand, Alam et al. (2020) observed a positive correlation of tuber yield with average tuber mass, and a negative correlation with the number of tubers per plant, whereas Khayatnezhad et al. (2011) showed a positive correlation between yield and average tuber mass, as well as the quantity of set tubers.

Table 4

Tabela 4

Pearson's correlation coefficients between the analyzed features of medium early cultivars of potato

Współczynniki korelacji Pearson’a pomiędzy analizowanymi cechami średnio wczesnych odmian ziemniaka

\begin{tabular}{cccccccc}
\hline Variables & $\mathrm{X}_{1}$ & $\mathrm{X}_{2}$ & $\mathrm{X}_{3}$ & $\mathrm{X}_{4}$ & $\mathrm{X}_{5}$ & $\mathrm{X}_{6}$ & $\mathrm{X}_{7}$ \\
\hline $\mathrm{X}_{1}$ & 1.00 & & & & & \\
$\mathrm{X}_{2}$ & $0.71^{* * *}$ & 1.00 & & & & \\
$\mathrm{X}_{3}$ & $-0.52^{* * *}$ & -0.08 & 1.00 & & & \\
$\mathrm{X}_{4}$ & $0.60^{* * *}$ & 0.15 & $-0.88^{* * *}$ & 1.00 & & & \\
$\mathrm{X}_{5}$ & 0.05 & $0.44^{* * *}$ & $0.43^{* * *}$ & $-0.30^{* * *}$ & 1.00 & & \\
$\mathrm{X}_{6}$ & $-0.37^{* * *}$ & 0.13 & $0.52^{* * *}$ & $-0.66^{* * *}$ & $0.43^{* *}$ & 1.00 & \\
$\mathrm{X}_{7}$ & -0.05 & $-0.44^{* * * *}$ & $-0.43^{* *}$ & $0.30^{* * *}$ & $-1.00^{* * *}$ & $-0.43^{* * *}$ & 1.00 \\
\hline
\end{tabular}

$X_{1}$ - total yield of tubers; $X_{2}$ - commercial yield of tubers; $X_{3}$ - average weight of tubers; $X_{4}-$ numer of tubers per plant; $X_{5}-$ share of commercial tubers; $X_{6}$ - share of large tubers; $X_{7}$ - share of small tubers

\section{Conclusions}

1. The size of yields and their structure were determined mostly by environmental factors. Only in the case of the share of fractions of large and small tubers were the varietal properties more decisive than the genotypic-environmental interaction.

2. Of the potato features that were evaluated, the share of the commercial tuber fraction was the most stable. Little diversity was also found in the case of the total and commercial yield of tubers. The share of the small tuber fraction turned out to be the least stable feature.

3. In the group of five medium-early cultivars of table potato, 'Laskara' was distinguished with the lowest variation with respect to yielding and shaping of the elements of yield structure, whereas 'Oberon' and 'Tajfun' cultivars were distinguished with the highest.

\section{Literature}

Alam, M. S, Islam, M. F., Rahman, M. S., Molla, M.M., Uddin, M.Z., Mian, M.A.K. 2020. Varietal evaluation and selection of yield-associated traits of potato (Solanum tuberosum) using correlation and path analysis in haor area of Moulvibazar, Bangladesh. Journal of Agricultural Science and Engineering Innovation 1 (1): 1-9.

Bussan, A. J., Mitchell, P. D., Copas, M. E., Drilias, M. J. 2007. Evaluation of the effect of density on potato yield and tuber size distribution. Crop Science 47: 2462-2472.

Chmura, K., Dzieżyc, H., Piotrowski, M. 2013. Response of medium early, medium late and late potatoes to water factor on wheat and rye soil complex. Infrastructure and Ecology of Rural Areas 2: 103-113.

Drzazga, T., Krajewski, P. 2001. Differentiation of locations with respect to the interaction with genotypes for series of winter wheat experiments. Bulletin IHAR 218/219: 111-115.

Gauch, H. G., Piepho, H. P., Annicchiarico, P. 2008. Statistical analysis of yield trials by AMMI and GGE. Further considerations. Crop Science 48: 866-889.

Jankowska, J., Pietraszko, M., Lutomirska, B. 2015. The analysis of yielding stability of some potato (Solanum tuberosum L.) cultivars on light soil. Fragmenta Agronomica 32 (3): $32-43$.

Khayatnezhad, M., Shahriari, R., Gholamin, R., Jamaatie-Somarin, S., Zabihi-e-Mahmoodabad, R. 2011. Correlation and path analysis between yield and yield components in potato (Solanum tubersum L.). MiddleEast Journal of Scientific Research 7 (1): 17-21.

Kołodziejczyk, M. 2014. Effect of nitrogen fertilization and microbial preparations on potato yielding. Plant, Soil and Environment 60 (8): 379-386.

Mądry, W., Iwańska, M. 2011. Usefulness of statistical methods and measures for evaluating cultivar stability and adaptation: an overview of research. Bulletin IHAR. 260/261: 193-217.

Nyc, K. 2006. Entering of irrigation systems. In: Water needs 
of crop plants. Eds. S. Karczmarczyk, L. Nowak, PWRiL Warsaw, pp. 157-174

Pytlarz-Kozicka, M. 2004. Planting density as a factor forming the structure of a potato plant. Bulletin IHAR 232: 113-119.

Radzka, E., Rymuza, K., Lenartowicz, T. 2015. Precipitation impact on yields of medium-early cultivars of edible potato in various regions of Poland. Acta Agrophysica 22 (4): 421-432.

Rijk, B., Ittersuma, M., Withagen, J. 2013. Genetic progress in Dutch crop yields. Field Crop Research 149: 262-268.

Rykaczewska, K. 2015. The effect of high temperature occurring in subsequent stages of plant development on potato yield and tuber physiological defects. American Journal of Potato Research 92 (3): 339-349.

Sawicka, B., Michałek, W., Pszczółkowski, P. 2011. Determinants of yield potential of medium-late and late potato cultivars in central-eastern Poland. Bulletin IHAR 259: 219-228.

Sawicka, B., Pszczółkowski, P. 2017. Phenotypic variation of the yield and its structure very early and early potato cultivars. Fragmenta Agronomica 34 (1): 76-91.

Stefańczyk, E., Śliwka, J. 2013. Effect of photoperiod on potato biology. Bulletin IHAR 267: 58-67.

Węgrzyn, S. 2001. An application of some statistical methods in plant breeding trials. Bulletin IHAR 218/219: 5-14.

Wierzbicka, A., Trawczyński, C. 2016. Yields potential and level of their utilization by the potato cultivars registered in the years 2006-2015. Fragmenta Agronomica 33 (4): 145-154.

Zabihi-e-Mahmoodabad, R., Jamaati-e-Somarin, S., Khayatnezhad, M., Gholamin, R. 2011. Correlation of tuber yield whit yield components of potato affected by nitrogen application rate in different plant density. Advances in Environtal Bioliogy 5 (1): 131-135. 